\title{
Seasonality in the infection and invasion of Marteilioides chungmuensis in the Pacific oyster Crassostrea gigas
}

\author{
Kay Lwin Tun ${ }^{1}$, Yasuko Shimizu ${ }^{2}$, Hideo Yamanoi ${ }^{2}$, Tomoyoshi Yoshinaga ${ }^{1}$, \\ Kazuo Ogawa ${ }^{1, *}$
}

${ }^{1}$ Laboratory of Fish Diseases, Department of Aquatic Bioscience, Graduate School of Agricultural and Life Sciences, University of Tokyo, Yayoi 1-1-1, Bunkyo, Tokyo 113-8657, Japan

${ }^{2}$ Fisheries Experiment Station of Okayama Prefecture, Ushimado, Setouchi 701-4303, Japan

\begin{abstract}
The protozoan parasite Marteilioides chungmuensis causes irregular enlargement of the ovary in the Pacific oyster Crassostrea gigas. The parasite invades the oyster through the epithelial tissue of the labial palp, replicates in the connective tissue, and then moves to the gonad, producing spores inside the oocytes. In this study the seasonality and invasion period of the parasite into the host was investigated over a 1 yr cycle. Uninfected 1 and 0 yr old (spat) oysters were placed in an epizootic area every month from July 2004 to July 2005 and September 2005 to March 2006, respectively, and left for 1 mo. Labial palps and gonad were sampled monthly and examined for infection by nested PCR and histological observations. Prevalence of infection detected by PCR was $70 \%$ or higher from August to October, but declined sharply in November and reached $7 \%$ or lower from February to April. To explain the low detection rate in winter, 1 yr old uninfected oysters were placed in an epizootic area in winter (water temperature: 8 to $10^{\circ} \mathrm{C}$ ) for $2 \mathrm{wk}$ and then transferred to $M$. chungmuensis-free seawater at $24^{\circ} \mathrm{C}$. Although prevalence of infection was ca. $7 \%$ before transfer to heated seawater, levels of $87 \%$ were detected after $1 \mathrm{wk}$. After a $3 \mathrm{wk}$ exposure to heated seawater, parasites were found in host oocytes by histological observation. It was concluded that the low prevalence in winter was due to insufficient replication of $M$. chungmuensis at low seawater temperatures, resulting in levels not detectable by nested PCR, and not to the absence of invasion.
\end{abstract}

KEY WORDS: Crassostrea gigas · Gonad development · Marteilioides chungmuensis · Invasion period $\cdot$ Parasite Resale or republication not permitted without written consent of the publisher

\section{INTRODUCTION}

Marteilioides chungmuensis, an ovarian protozoan parasite, is a major pathogen of Pacific oysters in Japan and Korea and a serious threat to the oyster culture industry (Matsusato \& Masumura 1981, Park \& Chun 1989, Imanaka et al. 2001, Itoh et al. 2002, Ngo et al. 2003, Park et al. 2003, Tun et al. 2006). A characteristic feature of the disease is the appearance of nodule-like structures on the gonad of female oysters. The abnormal appearance of infected oysters makes them unmarketable, resulting in serious economic losses for oyster-farmers (Itoh et al. 2002, Ngo et al. 2003).
Development and life cycle of Marteilioides chungmuensis in oysters had long remained unclear. However, the recent development of PCR and in situ hybridization techniques for detection of the parasite (Itoh et al. 2003a,b, 2004) has greatly advanced the understanding of the development of the parasite in oysters. According to previous studies (Itoh et al. 2002, 2003b, 2004), the development of the parasite is summarized as follows: an unknown infectious stage invades the oyster through the epithelial tissues of the gills, mantle and labial palps, replicates by binary fission in the connective tissue, migrates into gonad epithelium, multiplies there and invades oocytes, where it begins intracellular division and sporulation 
(Itoh et al. 2004). Ova containing spores of M. chungmuensis are released from the host body via the genital canal during spawning, which leads to the release of the parasite into the environment. However, the fate of released spores is still unknown. As direct transmission from host to host has not been shown, unknown intermediate hosts seem to be involved in the life cycle. The possible existence of an intermediate host for $M$. chungmuensis may be supported by the study on the related species, Marteilia refringens, in the flat oyster Ostrea edulis by Audemard et al. (2004), in which possible involvement of a copepod in the life cycle of the parasite as the intermediate host was demonstrated.

The seasonal fluctuation of Marteilioides chungmuensis infection in epizootic areas has been studied in Korea by Ngo et al. (2003) and Park et al. (2003) and in Japan by Imanaka et al. (2001) and Tun et al. (2007), using histological methods. They showed that prevalence increased from summer to autumn, when oysters were carrying oocytes, and decreased from winter to spring, when gonads were reverting to connective tissue after spawning. Ngo et al. (2003) postulated that since $M$. chungmuensis was not observed in oysters in the reproductively inactive stage in February and March, the parasites had been released from infected oysters in this period, had dispersed throughout the water column and had entered oysters during the early stages of gonad development in April or May. As gonad development progressed in summer, $M$. chungmuensis grew and reproduced inside the oocytes. From the above, one could conclude that parasites are present only in the period when oysters are carrying oocytes. However, life stages and seasonal prevalence of $M$. chungmuensis described by previous authors were studied only by microscopic observations. The molecular detection techniques for $M$. chungmuensis developed by Itoh et al. $(2002,2003 b)$ appeared to contribute much to our understanding of the seasonality and dynamics of parasite infections, which is of utmost importance for the development of effective programs to control the impact of the pathogen in endemic zones.

In the present study 3 experiments were carried out from 2004 to 2005, using the new molecular detection techniques along with a conventional histological technique to improve our knowledge of Marteilioides chungmuensis. The experiments were designed to (1) assess the seasonality of infection in an epizootic area, (2) determine the invasion period of the parasite in $1 \mathrm{yr}$ old oysters and oyster spat, i.e. oysters before oocyte development, and (3) evaluate the relation between water temperature and prevalence of infection.

\section{MATERIALS AND METHODS}

Oysters. Uninfected oyster spat were obtained from Tashirojima Island, Miyagi Prefecture $\left(38^{\circ} 04^{\prime} \mathrm{N}\right.$,

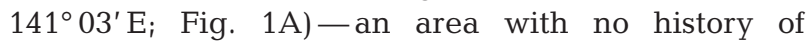
Marteilioides chungmuensis infection. Natural spat (seeds) spawned by wild or cultured oysters were collected in September 2003, using suspended collectors made of scallop shells. The spat was then reared on the shells on shelves in the intertidal zone in the uncontaminated area in Miyagi Prefecture before shipment for the present studies.

Prevalence of infection in epizootic area. Strings of scallop shells bearing oyster were shipped and held beneath a raft in the sea at the Fisheries Experiment
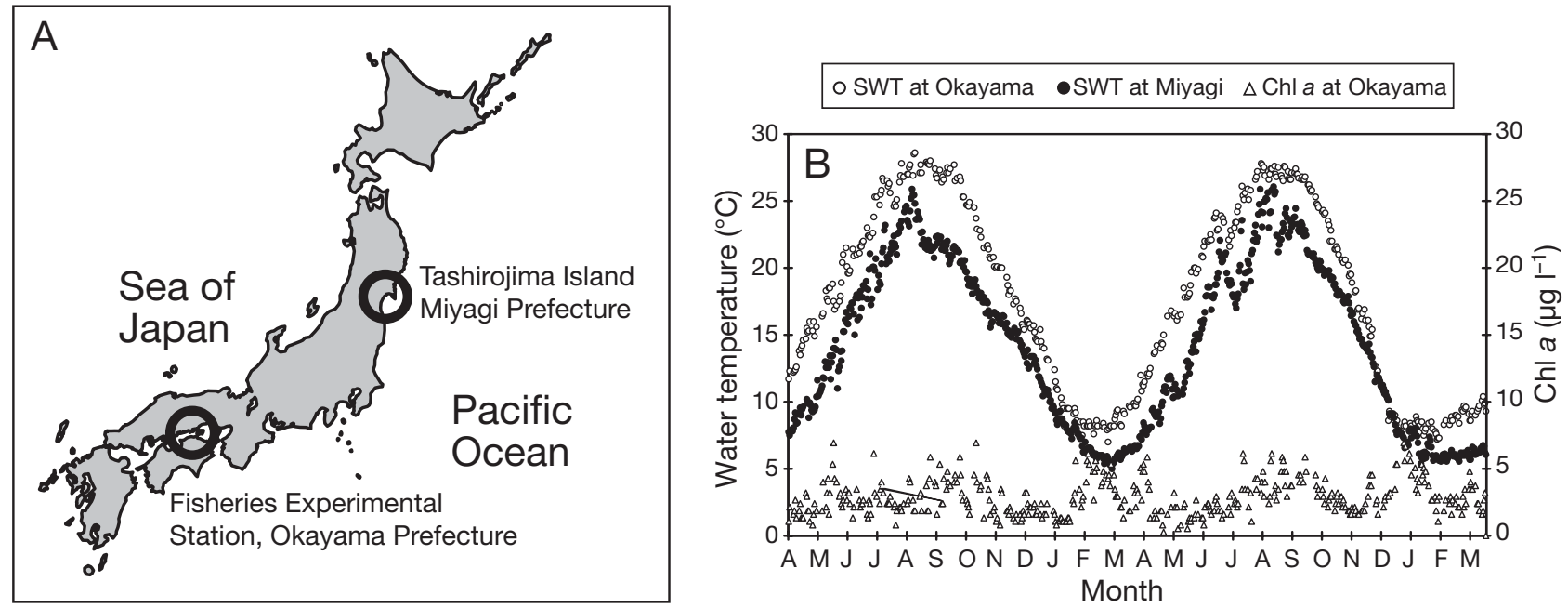

Fig. 1. (A) Locations of Tashirijima Island, Miyagi Prefecture and the Fisheries Experiment Station of Okayama Prefecture, Japan. (B) Environmental data at the locations (April 2004 to March 2006). Daily surface water temperatures (SWT) given for both locations; chlorophyll a concentrations given for the Fisheries Experimental Station of Okayama Prefecture only 
Station of Okayama Prefecture $\left(36^{\circ} 06^{\prime} \mathrm{N}, 131^{\circ} 04^{\prime} \mathrm{E}\right)$, an epizootic area for Marteilioides chungmuensis in May 2004 to assess the monthly prevalence of infection (Fig. 1A). From May 2004 to August 2005, 30 oysters were sampled monthly and gonads were examined by nested PCR and conventional histology for infection.

Procedures for histology and PCR. For histological observations, a $3 \mathrm{~mm}$ thick section was excised from the middle part of the body, fixed in Davidson's solution, dehydrated in an ethanol series and embedded in paraffin. Then, $5 \mu \mathrm{m}$ sections were prepared, stained with hematoxylin and eosin (H\&E) and checked for Marteilioides chungmuensis infection.

Nested PCR assays were performed as described in Itoh et al. (2003b). Briefly, gonad was excised and fixed in $100 \%$ ethanol for DNA extraction. DNA was extracted with DNeasy Tissue Kit (QIAGEN). NestedPCR reactions were performed using 2 sets of Marteilioides chungmuensis-specific primers, OPF-2/OPR-2 for the first round, and OPF-3/OPR-3 for the second round. PCR reactions were carried out in $20 \mu \mathrm{l}$ total volumes. PCR parameters for both rounds were as follows: $0.1 \mu \mathrm{l}$ of Takara Ex Taq ${ }^{\mathrm{TM}}(2.5 \mathrm{U}$ per $100 \mu \mathrm{l}) ; 2 \mu \mathrm{l}$ of $10 \times \mathrm{Ex} \mathrm{Taq}^{\mathrm{TM}}$ Buffer; $1.6 \mu \mathrm{l}$ of dNTP mix; $20 \mathrm{ng}$ of extracted DNA as template. The first thermal cycle protocol using the primers OPF-2/OPR-2 was as follows: pre-heating at $94^{\circ} \mathrm{C}$ for $5 \mathrm{~min}, 35$ cycles of denaturation at $94^{\circ} \mathrm{C}$ for $1 \mathrm{~min}$, annealing at $59^{\circ} \mathrm{C}$ for $30 \mathrm{~s}$, extension at $72^{\circ} \mathrm{C}$ for $1 \mathrm{~min}$, and a further elongation step at $72^{\circ} \mathrm{C}$ for $10 \mathrm{~min}$. An aliquot of $0.5 \mu \mathrm{l}$ of the first PCR product was used as a template for the second PCR step. The second-step PCR was the same as for the first-step PCR with the exception of a lower annealing temperature of $55^{\circ} \mathrm{C}$. PCR products were electrophoresed in $1.5 \%$ agarose gels.

In all 3 experiments oysters were examined with both nested PCR and histology, unless otherwise stated.

Invasion period of Marteilioides chungmuensis in Pacific oysters. Between 70 and 80 oysters were transferred from Miyagima Prefecture monthly and held beneath a raft in the sea for 1 mo at the Fisheries Experiment Station of Okayama Prefecture for exposure to the waterborne infective stage of the parasite and subsequent examination for infection.

Two batches of oysters were used in this experiment: 1 yr old oysters (mean height \pm SD: $72.35 \pm 4.76 \mathrm{~mm}$ ) spawned in the summer of 2003 and 0 yr old spat (mean height $\pm \mathrm{SD}: 27.5 \pm 4.88 \mathrm{~mm}$ ) spawned in the summer of 2005. The experiment was carried out from July 2004 to June 2005 for the 1 yr old oysters and from September 2005 to March 2006 for the 0 yr old spat. Before exposure in the epizootic area, labial palps (site of parasitic invasion) and part of the gonad (where the parasite matures) were excised from 10 oysters and fixed in $100 \%$ ethanol for DNA extraction and subjected to subsequent nested PCR assays to confirm that these oysters were not infected with the parasite. Gonadal development of oysters was histologically examined and categorized according to Heffernan et al. (1989).

Thirty oysters were randomly sampled from oysters hung in the epizootic area for 1 mo and examined by nested PCR and conventional histology.

Maintenance of oysters at high water temperature. One year old oysters were shipped from Miyagi Prefecture to the Fisheries Experiment Station of Okayama Prefecture in February 2005. Before the experiment commenced, 30 oysters were checked for the absence of infection by nested PCR and histological observations and their gonad development was assessed histologically.

Experimental group. Two hundred and fifty oysters were hung beneath a raft in the sea at the experimental station for $2 \mathrm{wk}$. They were cleaned of attached epifauna and transferred to a Marteilioides chungmuensis-free experimental tank containing $100 \mathrm{l}$ of $0.2 \mu \mathrm{m}$-filtered seawater. Water temperature in the experimental tank was raised by $2^{\circ} \mathrm{C} \mathrm{d}^{-1}$ until it reached $24^{\circ} \mathrm{C}$. Once the desired temperature was reached, it was maintained throughout the experiment. Oysters were fed daily with $10^{14}$ cells $\mathrm{d}^{-1}$ per oyster of algae Chaetoceros calcitrans purchased from Nisshin Oillio Ltd. Water in the tank was partially replaced every day with filtered seawater pre-heated to the same temperature in the tank.

Negative control tank group. Two hundred and fifty oysters from the same stock were transferred directly to another Marteilioides chungmuensis-free tank containing $100 \mathrm{l}$ of $0.2 \mu \mathrm{m}$-filtered seawater without being hung in the sea. Water temperature in the control tank was raised by $2^{\circ} \mathrm{C} \mathrm{d}^{-1}$ until it reached $24^{\circ} \mathrm{C}$ and maintained as described above for the experimental group.

Control group at the raft. Two hundred and fifty oysters from the same stock were maintained beneath a raft in the sea at the Fisheries Experiment Station of Okayama Prefecture throughout the experiment. Water temperature in the epizootic area during this period ranged between 7 and $10^{\circ} \mathrm{C}$.

For examination of Marteilioides chungmuensis infection, 30 oysters were randomly taken from the experimental group at the time they were transferred from the raft to the experimental tank. A second sample of 30 oysters was taken after holding at $24^{\circ} \mathrm{C}$ for $1 \mathrm{wk}$. In addition, 30 oysters were sampled 2 and $3 \mathrm{wk}$ after the beginning of the experiment.

For each of the 2 control group, 30 oysters were sampled at the same time as experimental oysters.

Prevalence of infection and gonad development were examined by nested PCR and conventional his- 
tology. Additionally, to locate the parasite within host tissues during the heating period, $5 \mu \mathrm{m}$ sections from the middle of the oysters were prepared for histological examination and in situ hybridization (ISH) as described by Itoh et al. (2003b). In brief, 3 oligonucleotide probes for the parasite, MCSP-01, MCSP-03 and 6-R, were labeled with digoxygenin (DIG) using a DIG oligonucleotide tailing kit (Roche). Hybridization reactions were performed with the MicroProbe Staining System (Fisher Scientific International) using manual capillary actions with modifications to the manufacturer's manual. A DIG nucleic acid detection kit (Roche) was used to visualize the hybridization products according to the manufacture's manual; sections were counterstained with $0.05 \%$ Bismarck brown Y (Sigma-Aldrich).

Environmental data. Surface water temperature was measured automatically with electronic thermometers equipped with remote data transmitting systems located at $1 \mathrm{~m}$ deep from the surface in the uncontaminated area in Miyagi Prefecture and in the epizootic area in Okayama Prefecture. Chlorophyll a levels were measured using the method of Lorenzen (1967) in the epizootic area. Daily temperature data measured in the uncontaminated areas at 15:00 $\mathrm{h}$ were provided by Miyagi Prefecture Fisheries Research and Development Center. Temperature data and chlorophyll a levels in the epizootic area were provided by the Fisheries Experiment Station of Okayama Prefecture.

\section{RESULTS}

\section{Environmental parameters in Okayama and Miyagi Prefectures}

Surface water temperature and chlorophyll a levels are presented in Fig. 1B. Water temperature in the epizootic area in Okayama Prefecture and in the uncontaminated area in Tashirojima Island Miyagi Prefecture, ranged from 7 to $29^{\circ} \mathrm{C}$ and 5 to $25^{\circ} \mathrm{C}$, respectively. From spring to autumn water temperature in Okayama Prefecture was 5 to $7^{\circ} \mathrm{C}$ higher than in Miyagi Prefecture while in winter it was 1 to $4^{\circ} \mathrm{C}$ higher in Miyagi Prefecture. In autumn, water temperatures differed most, with 25 to $27^{\circ} \mathrm{C}$ in Okayama and 19 to $20^{\circ} \mathrm{C}$ in Miyagi Prefecture. Chlorophyll a levels between the 2 locations could not be compared due to the absence of chlorophyll data on Tashirojima Island.

\section{Prevalence of infection in the epizootic area}

In oysters transferred to the epizootic area in Okayama Prefecture in May 2004, Marteilioides chung- muensis was found in June and August 2004 by nested PCR and histological observation, respectively. Using nested PCR, high prevalences of infection were detected from August to November. Prevalence reached a peak in November $(60 \%)$ and then declined gradually to $20 \%$ in May. In June 2005, prevalence of infection increased again and reached $80 \%$ in July (Fig. 2). In the histological observation, the prevalence of infection reached its peak in September $(40 \%)$ and then declined steadily to just $3 \%$ in the March to May period. In June 2005, the prevalence increased again with a second peak occurring in July $(49 \%), 2$ mo earlier than the first year peak (Fig. 2). Both young stage parasites (i.e. no spores inside cells) and advanced stage parasites (i.e. spores present inside the cells) were found from August to November 2004 (Fig. 3A), but only young stages were detected from December to May of the following year (Fig. 3B). In June and July 2005 , both early and advanced stage parasites were abundant.

\section{Invasion period of Marteilioides chungmuensis}

One-year-old oysters. Before being held in the epizootic area, oysters shipped from Miyagi Prefecture were histologically examined for gonad development. In July and August 2004, most transported oysters were in the developing or ripe stages. From September to February, all oysters were at the undifferentiated stage, i.e. spawning was completed and the gonad had disappeared and reverted to connective tissue. From March to June, gonad development had recommenced (Fig. 4A).

To assess the effect of water temperature on gonad development, oysters held in the epizootic area for $1 \mathrm{mo}$, where water temperature was consistently

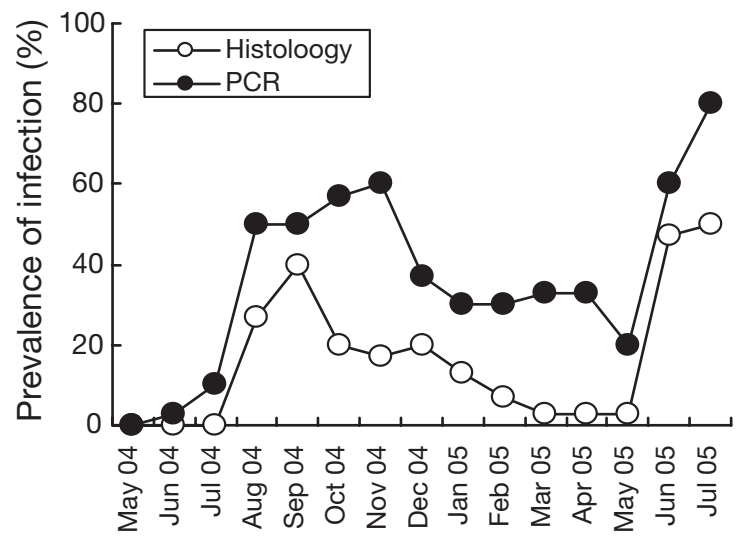

Fig. 2. Marteilioides chungmuenis infecting Crassostrea gigas. Prevalence of infection detected by histology (O) and nested PCR $(\bullet)$ in oysters reared in the epizootic area 

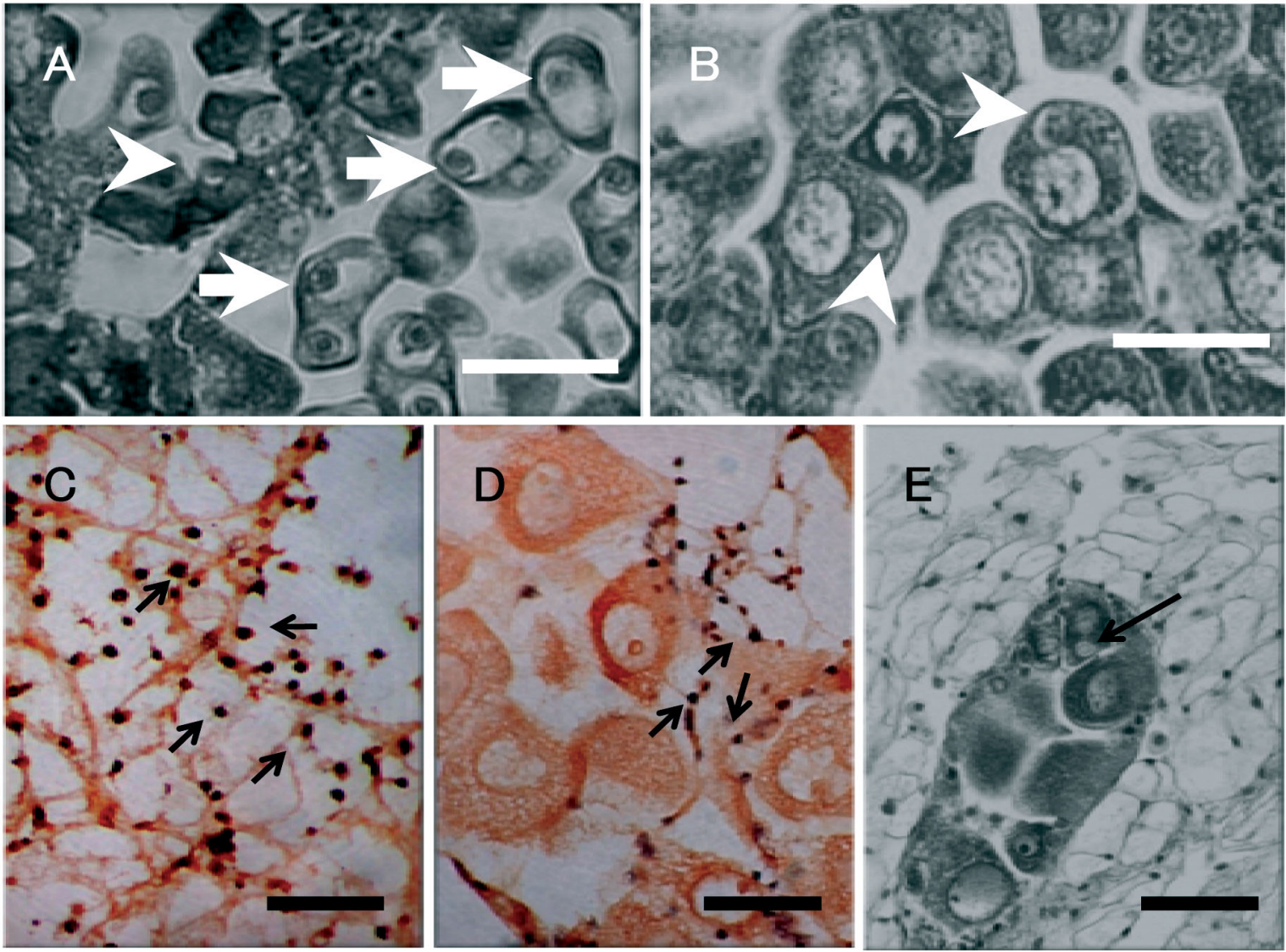

Fig. 3. Marteiloides chungmusensis infecting Crassostrea gigas. (A) Immature oocytes infected with an early-stage parasite (arrowhead) and mature oocytes with advanced-stage parasites (arrows) in an oyster in September 2004. Hematoxylin and eosin staining (H\&E). (B) Oocytes infected with early-stage parasites (arrowheads) in an oyster in December 2004 (H\&E). (C) Parasites (arrows) in the connective tissue of an oyster after $1 \mathrm{wk}$ exposure to the high temperature (in situ hybridization). (D) Parasites (arrows) near the follicle after $2 \mathrm{wk}$ exposure to the high temperature (in situ hybridization). (E) An early-stage parasite (arrow) in an oocyte attaching to the follicle of an oyster after $3 \mathrm{wk}$ exposure to the high temperature (H\&E). Scale bars $=50 \mu \mathrm{m}$

higher than that in the uninfected area (Miyagi), were examined. Gonad development progressed rapidly from the undifferentiated to the spawning stage after the start of the holding period (Fig. 4B), with rapid progression being observed in October and November. Although gonads were in the undifferentiated stage before exposure to the epizootic area during October and November, they progressed to the spawning and spent stage after 1 mo exposure.

After 1 mo exposure in the epizootic area, Marteilioides chungmuensis invasion was examined by nested PCR and histological observation. High prevalence of infection was detected from August to October in both the labial palps and gonad by nested PCR (Fig. 4C). Prevalence reached a peak in October (86\%) and then declined to $3 \%$ during January to April 2005. Thereafter, prevalence steadily increased to ca. $30 \%$ in July.

From histological observations, high prevalence was detected in August through October, but no infection was detected from December to May (Fig. 4D). In July 2005 , high prevalence $(27 \%)$ was again observed. It was evident from the relationship between prevalence of infection (Fig. 4D) and gonad development (Fig. 4B) that a high prevalence was correlated with the ripe and spawning stages, i.e. the period when oysters are carrying mature oocytes.

Both young and advanced stage parasites were found in July to September, while only young stage parasites were found in October and November. In June and July of the following year, both young and advanced stage parasites were found again.

Water temperature was 20 to $26^{\circ} \mathrm{C}$ when prevalence of infection was high and advanced stage parasites were observed. Temperature was $<18^{\circ} \mathrm{C}$ when prevalence of infection was low and only young stage parasites were observed.

0-year-old oysters. Although oyster spat did not bear oocytes throughout the experimental period, a high prevalence of infection was detected by nested PCR in 

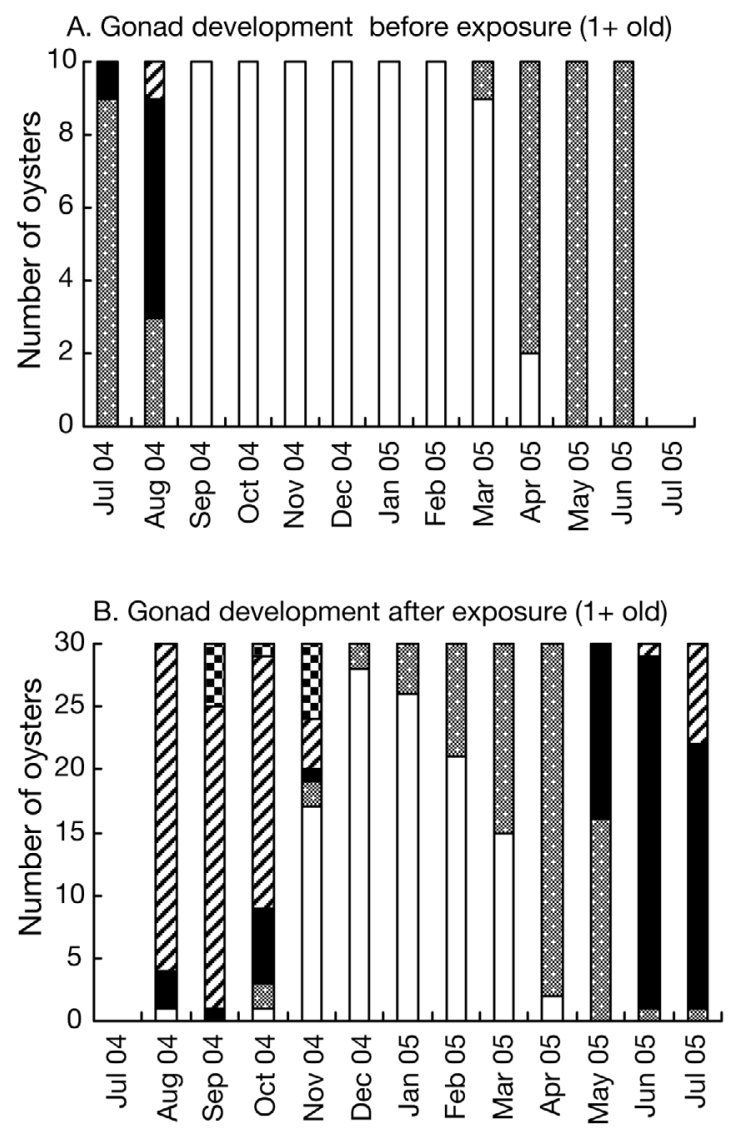

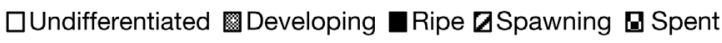

Fig. 4. Marteilioides chungmuensis infecting Crassostrea gigas. Gonad development and $M$. chungmuensis infection in oysters placed in the epizootic water for $1 \mathrm{mo}$. Gonad development in (A) $1 \mathrm{yr}$ old oysters before exposure, or (B) $1 \mathrm{yr}$ old oysters after exposure. Prevalence detected by (C) nested PCR in the labial palps and gonad of $1 \mathrm{yr}$ old oysters after exposure, (D) histology in the gonad of $1 \mathrm{yr}$ old oysters after exposure, (E) nested PCR in the labial palps and gonad of 0 yr old oysters

October $(82 \%)$ after which the prevalence declined suddenly to $17 \%$ in November. Thereafter, a prevalence of 3 to $10 \%$ was detected until the end of the experiment (Fig. 4E). No infection was detected by histological observation.

\section{Maintenance of oysters at high water temperature}

No mortality occurred in oysters in the experimental or control groups. Gonad development was found in some oysters maintained at $24^{\circ} \mathrm{C}$ for $1 \mathrm{wk}$, though they
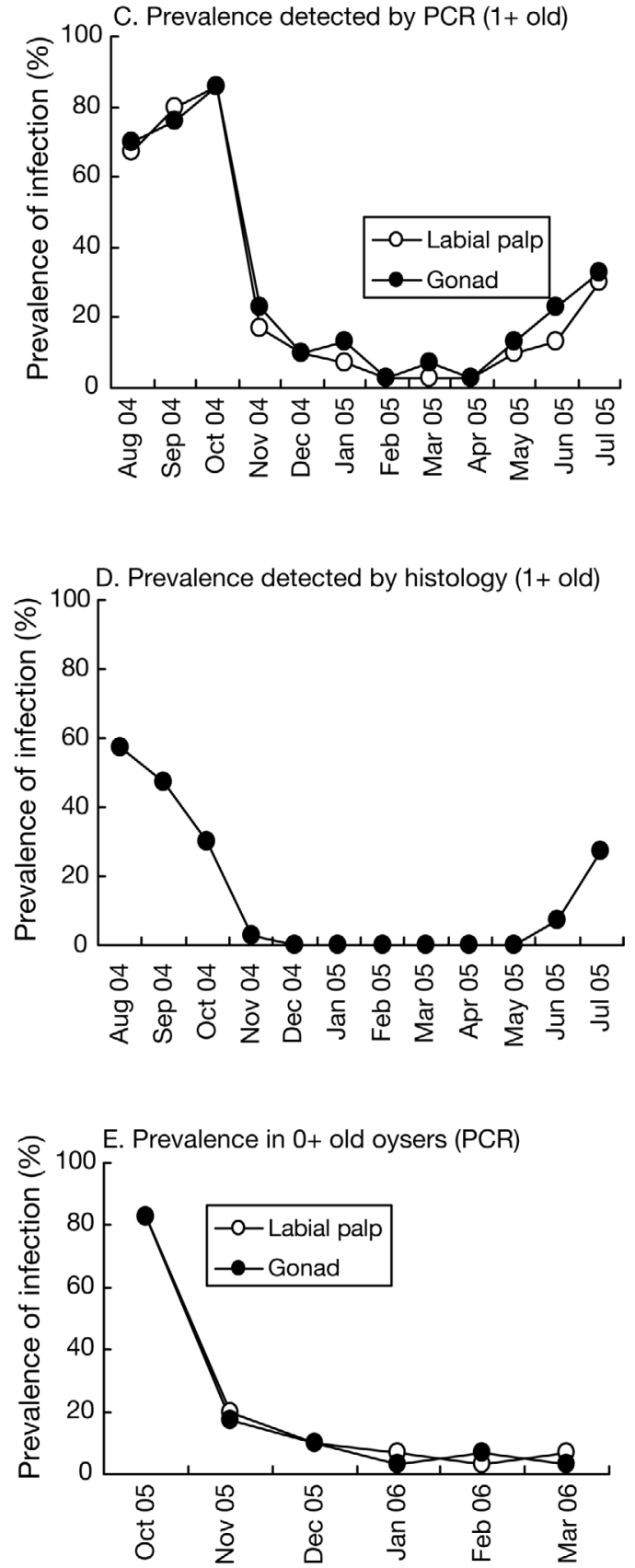

were at the undifferentiated stage when transferred from the epizootic area to the experimental tank (Fig. 5A). After 2 wk in the experimental tank, gonad development in most oysters had progressed to the last phase of the developing stages; except for some areas, the gonad was filled with mature and immature oocytes.

Prevalence of infection in the experimental group, examined by nested PCR, rose suddenly from 6 to $87 \%$ in the labial palps and 3 to $93 \%$ in the gonad of oysters maintained at $24^{\circ} \mathrm{C}$ for $1 \mathrm{wk}$. After 2 and $3 \mathrm{wk}$, prevalence decreased to 40 and $23 \%$ in the gonad and 27 


\section{A. Gonad development}
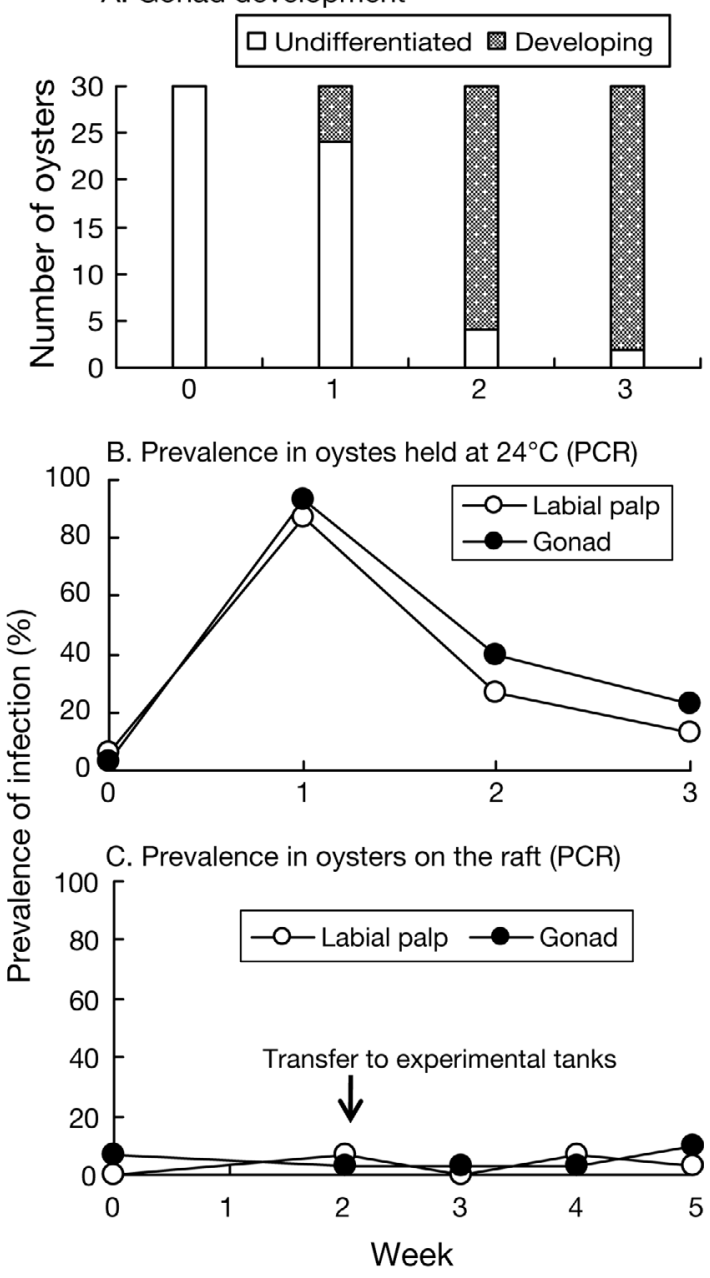

Fig. 5. Marteilioides chungmuensis infecting Crassostrea gigas. Gonad development and $M$. chungmuensis infection by nested PCR in oysters reared at the high temperature of $24^{\circ} \mathrm{C}$. (A) Gonad development and (B) prevalence of infection during the rearing period. (C) Prevalence in oysters reared at ambient water temperature. Weeks 2, 3, 4 and 5 in (C) correspond to Weeks $0,1,2$ and 3 in (B), respectively

and $13 \%$ in the labial palps, respectively (Fig. 5B). The prevalence in the experimental group was significantly different from those in the 2 control groups (negative and raft) in both the labial palps and gonad after the first week $\left(\chi^{2}\right.$ test, $\left.p<0.05\right)$. However, no significant difference was detected between the experimental and the raft control group in the prevalence in the labial palps in the third week.

No infection was detected in the negative control group held in heated seawater, while a prevalence of 3 to $10 \%$ was noted in the raft control group (Fig. 5C). In all experiments, there was no significant difference in prevalence of infection between the labial palps and gonad.
ISH was used to confirm the location of parasites inside the tissue of oysters held at $24^{\circ} \mathrm{C}$. In oysters maintained at this temperature for $1 \mathrm{wk}$, Marteilioides chungmuensis was detected in the connective tissue of the gill, mantle and labial palps (Fig. 3C). After 2 and $3 \mathrm{wk}$, clusters of parasites were found near the gonadal follicles (Fig. 3D). Parasites were observed histologically inside immature oocytes of oysters held for $3 \mathrm{wk}$ in heated seawater (Fig. 3E).

\section{DISCUSSION}

\section{Invasion period of Marteilioides chungmuensis}

Itoh et al. (2004) demonstrated that Crassostrea gigas became infected first in the palp, gill and mantle and later in the oocytes when exposed in an epizootic area of Marteilioides chungmuensis. In the present study, labial palps (site of parasitic invasion) and part of the gonad (where the parasite matures) of oysters placed in an epizootic area for 1 mo were examined to investigate the invasion period of $M$. chungmuensis. A high prevalence of infection was detected in the labial palps and gonad of both 1 and 0 yr old oysters from May to November, showing that the parasite invaded oysters during this 7 mo period (Fig. 4C). Furthermore, the time of exposure required by oysters to become infected was confirmed to be $<1$ mo.

In contrast to the period when prevalence was high, prevalence of infection was low from December to April in both the labial palps and gonad, as assessed by nested PCR in the 2 batches of oysters. Although the prevalence of infection differed between the nested PCR method and histological observations, the general trend was similar with both methods.

High prevalence of infection and infection intensity of Marteilioides chungmuensis have previously been found to be correlated with high water temperatures (Imanaka et al. 2001, Ngo et al. 2003). This agrees with the present study where high prevalence of infection and advanced stage parasites were found in the gonad of $1 \mathrm{yr}$ old oysters from June/July to September when water temperature was $>20^{\circ} \mathrm{C}$, whereas low prevalence of infection and only young stage parasites were detected in October and November when water temperature was $<18^{\circ} \mathrm{C}$. Audemard et al. (2004) considered that a temperature of $>17^{\circ} \mathrm{C}$ is required for Marteilia refringens, another paramyxean parasite, to infect the flat oyster Ostrea edilus. Similarly, the present results suggest that a temperature of $>18^{\circ} \mathrm{C}$ would be needed to allow the invasion of $M$. chungmuensis in Pacific oysters. 


\section{Dynamics of Marteilioides chungmuensis infection at high water temperature}

Although infection prevalence was very low from December to April when we studied the invasion period of Marteilioides chungmuensis, no conclusion could be reached regarding the invasion period because water temperature during this period was $<7^{\circ} \mathrm{C}$. Thus, the parasite may not be able to develop at such low temperatures, as temperature is considered to be a main parameter in the sporulation process of $M$. chungmuensis (Ngo et al. 2003). An additional experiment, which examined the maintenance of oysters at high water temperature, was conducted to clarify the relation between the infection intensity and water temperature.

Since high prevalence of infection was detected in the epizootic area when water temperature was $>20^{\circ} \mathrm{C}$, an experiment was designed in which oysters were maintained at $24^{\circ} \mathrm{C}$ after being held in the epizootic area during winter. The initial infection rate was 3 to $7 \%$ before the oysters were transferred to the heated water from the raft where water temperature was $<7^{\circ} \mathrm{C}$. After being held for $1 \mathrm{wk}$ at $24^{\circ} \mathrm{C}$ the detected prevalence of infection was $>80 \%$ in the labial palps and oocytes. After 3 wk at $24^{\circ} \mathrm{C}$, sporulation stage parasites were detected in oocytes with $\mathrm{H} \& \mathrm{E}$ staining.

Itoh et al. (2004) studied the initial developmental stages and life cycle of Marteilioides chungmuensis within the host during the summer season and reported binary fission in the connective tissue of the labial palps and gills before the parasite invaded the oocytes. Kleeman et al. (2002) observed similar developmental stages of Marteilia sydneyi in the Sydney rock oyster Saccostrea glomerata where the parasite undergoes cell-in-cell replication in the labial palps and gill epithelia of the host. It is probable that $M$. chungmuensis cannot multiply via binary fission at low temperatures, since nested PCR detection generally proved negative. However, high prevalence of infection was detected in the labial palps and gonad of oysters held at a high temperature for $1 \mathrm{wk}$, leading us to speculate that $M$. chungmuensis could begin replication at high water temperatures. Thus, invasion of $M$. chungmuensis in Crassostrea gigas may occur all year round but have been undetectable in winter/spring because the parasites could not multiply to detectable levels at low water temperatures.

Interestingly, it takes only $1 \mathrm{wk}$ for parasitic multiplication inside the labial palps and transfer to the gonad when water temperature is maintained at $24^{\circ} \mathrm{C}$. Furthermore, there was no significant difference in the prevalence of infection between the labial palps and gonad, suggesting that the developmental cycle within the host is very short at high temperatures.
However, the prevalence of infection in both the labial palps and gonad decreased suddenly 2 and $3 \mathrm{wk}$ after exposure. Itoh et al. (2004) investigated the prevalence of infection in male and female oysters exposed in an epizootic area in August and found that prevalence began to decrease in male oysters after $4 \mathrm{wk}$, while prevalence increased continuously in female oysters. They concluded that Marteilioides chungmuensis invaded male oysters as well, but may have been excluded from the oysters without initiating sporulation, which occurs inside the oocytes only. In contrast, our findings showed that most oysters were at the undifferentiated stage or developing stages. It could be considered that the decrease in prevalence of infection after $1 \mathrm{wk}$ was not because of exclusion of parasites by male oysters but because immature oysters provide favorable conditions for development of parasites. Therefore, $M$. chungmuensis invaded and multiplied during the first week in heated seawater but could not continue normal development. Owing to the mismatch between the development of $M$. chungmuensis and gonadal development in heated seawater, the parasite could be released and/or degraded by the hosts after $2 \mathrm{wk}$ resulting in decreased prevalence of infection.

When oyster spat were transferred from Miyagi to Okayama in October 2005, it experienced an increase of ambient water temperature from ca. 20 to $27^{\circ} \mathrm{C}$ (Fig. 1B) and developed from undifferentiated stage to ripe and spawning stages (Fig. 4A, B). Also, $>80 \%$ and ca. $30 \%$ were found to be infected by PCR and histology detection, respectively (Fig. 4C, D), in $1 \mathrm{mo}$. On the other hand, in the heating experiment, oysters maintained at $24^{\circ} \mathrm{C}$ for $3 \mathrm{wk}$ were still at the late developing stage. The slower gonad development in the latter oysters was probably due to the lower temperature $\left(24^{\circ} \mathrm{C}\right)$ and the shorter experimental period $(3 \mathrm{wk})$. Considering that Deslous-Paoli \& Héral (1988), Kang et al. (2000) and Delaporte et al. (2006) demonstrated that the reproductive condition of oysters could be affected by food availability as well as temperature, insufficient nutrition might be another possible cause of the delayed development of the gonad.

Audemard et al. (2004) studied the infection period of Marteilia refringens in the flat oyster Ostrea edulis by holding batches of uninfected oysters in an epizootic area for 1 mo each month from March to September, and then transferred them to $M$. refringens-free conditions. $M$. refringens was only detected in June to August when water temperature exceeded $17^{\circ} \mathrm{C}$. They concluded that $17^{\circ} \mathrm{C}$ was the minimum temperature required for parasite transmission. However, maintenance of exposed flat oysters at high temperatures during the winter period was not carried out. If this had been done, results similar to ours may have been obtained. 


\section{Seasonal variation of Marteilioides chungmuensis infection}

In histological observations, prevalence of infection decreased from October to May. Tun et al. (2008) revealed that the prevalence of infection decreased in October to December due to mortality of oysters, while the decrease in prevalence in February to April was due to the recovery of oysters because parasites were not histologically detected in the gonad of previously infected oysters. However, in the present study prevalence of infection detected by PCR was still high in November to March, suggesting that parasites could exist in recovered oysters but that this stage could not be detected by histology. Therefore, parasites can exist in the oyster in all seasons in an epizootic area.

\section{CONCLUSION}

With respect to the life cycle of Marteilioides chungmuensis, cohabitation with infected oysters and feeding of spore stage failed to transmit infection to uninfected oysters (Itoh et al. 2004), suggesting that this ovarian parasite may require an intermediate host. Since $M$. chungmuensis invades oysters in all seasons, parasites of infective stages are probably released from the intermediate host all year round.

Although 0 yr old spats did not bear oocytes during the experimental period, a high prevalence of infection was detected, indicating that Marteilioides chungmuensis could invade and exist in oyster spats within 1 mo of settlement on collectors. In conclusion, results from the present experiments suggest that oysters should be maintained in quarantine facilities for $1 \mathrm{wk}$ at $24^{\circ} \mathrm{C}$ before being tested by nested PCR in the context of a surveillance program for the M. chungmuensis-free demonstration.

Acknowledgements. The staff of the Fisheries Experiment Station of Okayama Prefecture and Fisheries Research and Development Center of Miyagi Prefecture are thanked for their assistance in sampling and providing us with environmental data. Thanks are also due to Dr. H. Yokoyama (University of Tokyo) for his critical review of the manuscript.

\section{LITERATURE CITED}

Audemard C, Sajus MC, Barnaud A, Sautour B, Sauriau PG, Berthe FCJ (2004) Infection dynamics of Marteilia refringens in flat oyster Ostrea edulis and copepod Paracartia grani in a claire pond of Marennes-Oléron Bay. Dis Aquat Org 61:103-111

$>$ Delaporte M, Soudant P, Lambert C, Moal J, Pouvreau S, Samain JF (2006) Impact of food availability on energy storage and defense related hemocyte parameters of the Pacific oyster Crassostrea gigas during an experimental reproductive cycle. Aquaculture 254:571-582

> Deslous-Paoli JM, Héral M (1988) Biochemical composition and energy value of Crassostrea gigas (Thunberg) cultured in the bay of Marennes-Oléron. Aquat Living Resour $1: 239-249$

Heffernan PB, Walker RL, Carr JL (1989) Gametogenic cycles of three bivalves in Wassaw Sound, Georgia: II. Crassostrea virginica (Gmelin, 1791). J Shellfish Res 8:61-70

Imanaka S, Itoh N, Ogawa K, Wakabayashi H (2001) Seasonal fluctuations in the occurrence of abnormal enlargement of the ovary of Pacific oyster Crassostrea gigas at Gokasho Bay, Mie, Japan. Fish Pathol 36:83-91

Itoh N, Oda T, Ogawa K, Wakabayashi H (2002) Identification and development of a paramyxean ovarian parasite in the Pacific oyster. Fish Pathol 37:23-28

> Itoh N, Oda T, Yoshinaga T, Ogawa K (2003a) Isolation and $18 \mathrm{~S}$ ribosomal DNA genes sequences of Marteilioides chungmuensis (Paramyxea), an ovarian parasite of the Pacific oyster Crassostrea gigas. Dis Aquat Org 54: 163-169

Itoh N, Oda T, Yoshinaga T, Ogawa K (2003b) DNA probes for detection of Marteilioides chungmuensis from the ovary of Pacific oyster Crassostrea gigas. Fish Pathol 38:163-169

Itoh N, Komiyama H, Ueki N, Ogawa K (2004) Early developmental stages of a protozoan parasite, Marteilioides chungmuensis (Paramyxea), the causative agent of the ovary enlargement disease in the Pacific oyster, Crassostrea gigas. Int J Parasitol 34:1129-1135

Kang CK, Park MS, Lee PY, Choi WJ, Lee WC (2000) Seasonal variations in condition, reproductive activity, and biochemical composition of the Pacific oyster, Crassostrea gigas (Thunberg), in suspended culture in two coastal bays of Korea. J Shellfish Res 19:771-778

$>$ Kleeman SN, Adlard RD, Lester RJG (2002) Detection of the initial infective stages of the protozoan parasite Marteilia sydneyi in Saccostrea glomerata and their development through to sporogenesis. Int J Parasitol 32:767-784

Lorenzen CJ (1967) Determination of chlorophyll and phaeopigments: spectrophotometric equations. Limnol Oceanogr 12:343-346

Matsusato T, Masumura K (1981) Abnormal enlargement of the ovary of oyster, Crassostrea gigas (Thunberg) by an unidentified parasite. Fish Pathol 15:207-212

Ngo TTT, Berthe FCJ, Choi KS (2003) Prevalence and infection intensity of the ovarian parasite Marteilioides chungmuensis during an annual reproductive cycle of the oyster Crassostrea gigas. Dis Aquat Org 56:259-267

Park MS, Chun SK (1989) Study on Marteilioides chungmuensis Comps et al. 1986, parasite of the Pacific oyster, Crassostrea gigas Thunberg. J Fish Pathol 2:53-70 (in Korean with English abstract)

Park MS, Kang CK, Choi DL, Jee BY (2003) Appearance and pathogenicity of ovarian parasite Marteilioides chungmuensis in the farmed Pacific oysters, Crasssostrea gigas, in Korea. J Shellfish Res 22:475-479

Tun KL, Itoh N, Komiyama H, Ueki N, Yoshinaga T, Ogawa K (2006) Comparison of Marteilioides chungmuensis infection in the Pacific oyster Crassostrea gigas cultured in different conditions. Aquaculture 253:91-97

Tun KL, Itoh N, Ueki N, Yoshinaga T, Ogawa K (2007) Relationship between Marteilioides chungmuensis infection and reproduction in the Pacific oyster, Crassostrea gigas. J Invertebr Pathol 96:205-212

Tun KL, Itoh N, Shimizu Y, Yamanoi H, Yoshinaga T, Ogawa K (2008) Pathogenicity of the protozoan parasite Marteilioides chungmuensis in the Pacific oyster Crassostrea gigas. Int J Parasitol 38:211-217 